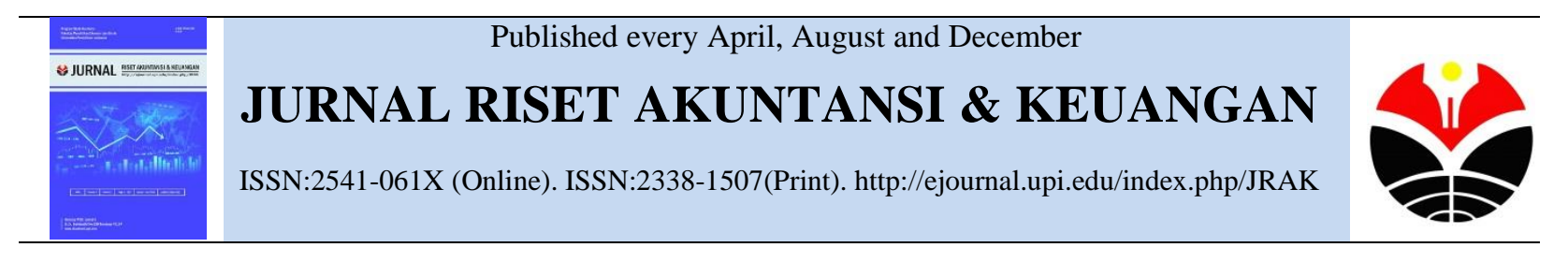

\title{
Implementasi Penentuan Harga Pokok Produksi Untuk Mencapai Laba Optimal (Studi Pada Sentra UKM Industri Bakpia Di Wilayah Minomartani Sleman Yogyakarta)
}

\section{Wiratna Sujarweni \\ Program Studi Akuntnasi, FE, Universitas Respati Yogyakarta,Indonesia}

\begin{abstract}
The calculation on cost production has important roles in companies such as to determine the selling price, the right cost production can give optimum profit. The research aims are to identify and analyze the cost production price on SME Bakpia industrial by using regular methods applied by UKM during the time and by using methods based on accounting cost which are costing target and ABC (Activity Based Costing) method. The population in the research were SME Bakpia industry in Minomartani Sleman Yogyakarta. The research sampling used incidental sampling technique. The data used production data. This research was descriptive qualitative and comparative quantitative research by using descriptive analysis device and independent statistical test of $t$-test sample. The result obtained that from 30 Bakpia SME in Minomartani Sleman, only 13 SME of Bakpia set the selling price using cost production methods, meanwhile 17 SME of Bakpia set the selling price based on market price. The cost of Bakpia production based on SME calculation was 831.67 rupiahs per item, based on cost production of costing target was 729.17 rupiahs, meanwhile based on ABC method was 722.51 rupiahs. The recommended method to calculate cost production was ABC method because it had the lowest price of cost production, so the profit would be optimum. There is a difference profit between SME of Bakpia that applied the cost production methods and the SME that didn't apply the cost production method. The Bakpia SME that did not use the cost production gained low profit than the Bakpia SME used the cost production calculation.. Keywords: Cost Production Price (CPP), profit, Small Medium Enterprises (SME), Costing Target.
\end{abstract}

Abstrak. Perhitungan biaya produksi memiliki peran penting dalam perusahaan seperti menentukan harga jual, biaya produksi yang tepat dapat memberikan keuntungan yang optimal. Tujuan penelitian ini adalah untuk mengetahui dan menganalisis harga produksi biaya industri UKM Bakpia dengan menggunakan metode reguler yang diterapkan oleh UKM selama ini dan dengan menggunakan metode berdasarkan biaya akuntansi yaitu metode penetapan harga dan metode ABC (Activity Based Costing). Populasi dalam penelitian ini adalah industri UKM Bakpia di Minomartani Sleman Yogyakarta. Sampel penelitian menggunakan teknik accidental sampling. Data menggunakan data produksi. Penelitian ini merupakan penelitian deskriptif kualitatif dan komparatif kuantitatif dengan menggunakan alat analisis deskriptif dan uji statistik independen terhadap sampel t-test. Hasilnya diperoleh dari 30 UKM Bakpia di Minomartani Sleman, hanya 13 UKM Bakpia yang menetapkan harga jual dengan menggunakan metode biaya produksi, sedangkan 17 UKM Bakpia menetapkan harga jual berdasarkan harga pasar. Biaya produksi Bakpia berdasarkan perhitungan UKM adalah 831,67 rupiah per item, berdasarkan biaya produksi dengan target biaya sebesar 729,17 rupiah, sedangkan berdasarkan metode $\mathrm{ABC}$ adalah 722,51 rupiah. Metode yang disarankan untuk menghitung biaya produksi adalah metode ABC karena memiliki harga produksi biaya terendah, sehingga keuntungannya akan optimal. Ada perbedaan keuntungan antara UKM Bakpia yang menerapkan metode biaya produksi dan UKM yang tidak menerapkan metode biaya produksi. UKM Bakpia yang tidak menggunakan biaya produksi memperoleh keuntungan rendah dibandingkan dengan Bakpia yang menggunakan perhitungan biaya produksi.

Kata Kunci: Harga Produksi (CPP), Laba Usaha Kecil Menengah (UKM), Target Biaya

Corresponding author. Email: nana_wiratna @ yahoo.com.

How to cite this article. V Sujarweni, V. W. (2016). Implementasi Penentuan Harga Pokok Produksi Untuk Mencapai Laba Optimal. Jurnal Riset Akuntansi Dan Keuangan Program Studi Akuntansi Fakultas Pendidikan Ekonomi Dan Bisnis Universitas Pendidikan Indonesia, 4(3), 1111-1124. Retrieved from http://ejournal.upi.edu/index.php/JRAK/article/view/4665

History of article. Received: September 2016, Revision: November 2016, Published: December 2016

Online ISSN: 2541-061X.Print ISSN: 2338-1507. DOI: 10.17509/jrak.v4i3.4665

Copyright $\odot 2016$. Published by Jurnal Riset Akuntansi dan Keuangan. Program Studi Akuntansi. FPEB. UPI 


\section{PENDAHULUAN}

Usaha kecil dan menengah (UKM) mempunyai peran yang cukup penting dalam membangun perekonomian di Indonesia. Terbukti di saat krisis ekonomi melanda Indonesia, pemerintah sangat mengandalkan peran UKM untuk memperkecil dampak negatif dari krisis ekonomi. UKM merupakan solusi untuk menyerap tenaga kerja yang diberhentikan akibat PHK (Pemutusan Hubungan Kerja) dan juga memberikan sumber pendapatan tambahan bagi tenaga kerja. Dalam menjalankan tugas dan fungsinya ada banyak faktor yang sangat diperlukan oleh manajemen suatu UKM, salah satunya adalah informasi. Informasi merupakan fakta, data, pengamatan, persepsi atau sesuatu yang lain, yang menambah pengetahuan. Informasi diperlukan manusia untuk mengurangi ketidakpastian dalam pengambilan keputusan.

Suatu usaha pada umumnya bertujuan mendapatkan laba yang optimal, hal ini dimaksudkan agar tetap bertahan dan mampu bersaing di era global dan MEA khususnya. UKM harus memiliki strategi dan kebijakan yang tepat, salah satu strategi dan kebijakan yang harus ditetapkan perusahaan adalah kebijakan tentang penentuan HPP (harga pokok produk) yang dihasilkan perusahaan. Akuntansi biaya dalam perhitungan ini berperan menetapkan, menganalisa dan melaporkan pos-pos biaya yang mendukung laporan keuangan. Dalam akuntansi biaya ini menyediakan data-data biaya usaha digolongkan dan dilakukan pencatatan untuk menentukan harga pokok produksi yang akurat.

Perhitungan Harga pokok produksi yang sesungguhnya diperlukan untuk usaha, selain untuk menentukan harga jual yang sesungguhnya agar lebih dapat bersaing dalam hal harga jual dengan usaha kecil lainnya, juga dapat untuk mengidentifikasi biaya produksi sehingga jika memang diperlukan untuk memperkecil biaya maka dapat diidentifikasikan biaya mana yang dapat dikurangi untuk mendapatkan HPP yang lebih murah.
Bakpia adalah salah satu yang menjadi ikon oleh-oleh khas Jogja, pada awalnya bakpia lebih dikenal masyarakat dibuat di wilayah Pathuk Yogyakarta, seiring perkembangan waktu dan perkembangan pariwisata di Yogyakarta, warga Minomartani kemudian merintis industri rumahan untuk memproduksi bakpia. Ketekunan dan keuletan para ibu-ibu ini membuahkan hasil yaitu dengan berkembangnya perkampungan Minomartani menjadi sentra industri bakpia. Tahun 2011 pemerintah Kabupaten Sleman menetapkan Minomartani yang berada di Kecamatan Ngaglik sebagai sentra kuliner bakpia. Bakpia Mino dibuat secara perorangan oleh warga komplek perumahan Minomartani yang pusatnya berada di jalan Tenggiri dan Mujahir. Saat ini ada sekitar 50 outlet bakpia di perumahan Minomartani tersebut. Pemerintah memberi perhatian dan dukungan terus kepada UKM ini.

Walaupun industri ini sudah berdiri bertahun-tahun, namun banyak dari mereka masih mengalami kesulitan dalam menentukan harga. Dari hasil survei yang dilakukan oleh peneliti bahwa Industri Bakpia di Minomartani Sleman tersebut banyak yang mempunyai permasalahan tidak membuat pembukuan dan kesulitan dalam menentukan harga pokok produksinya, sehingga dalam penentuan harga jual mereka masih menggunakan harga pasaran. Dari 30 UKM Bakpia yang ada di sentra Bakpia Minomartani Sleman, hanya 13 UKM yang menetapkan harga jualnya dengan menggunakan harga pokok produk, sedangkan 17 UKM lainnya menetapkan harga jual berdasarkan harga pasaran, walaupun perhitungan mereka masih menggunakan metode yang hanya memperhitungkan biaya bahan baku, biaya tenaga kerja, dan biaya lain-lain. Dari ke 13 UKM yang sudah menghitung harga pokok tersebut ada $1 \mathrm{UKM}$ yang melakukan perhitungan HPP dengan rinci. Jika melihat hasil pra surve ini sungguh sangat disayangkan jika UKM bakpia yang sudah berdiri bertahun-tahun ini tidak memperhatikan aspek harga produksi, akibatnya UKM tidak berani menaikkan kualitas karena jika menaikkan kualitas akan 
berpengaruh pada biaya-biaya dan akan meningkatkan harga jual. Untuk dapat menaikan kualitas, jika UKM dapat mengetauhui cara tepat perhitungan HPP maka akan mengetahui biaya mana saja yang dapat ditekan dan mana yang tidak.

Penulis sangat tertarik untuk mengangkat topik penelitian ini, penelitian ini akan melakukan perhitungan HPP dengan cara mengambil data produksi dari UKM bakpia yang ada di wilayah Minomartani, kemudian meneliti bagi UKM yang sudah melakukan perhitungan HPP selama ini seperti apa. Selanjutnya peneliti akan menghitungkan HPP berdasarkan tradisionel dan berdasarkan teori dalam akuntansi biaya yaitu dengan metode target costing dan Activity Based Costing(ABC). Kemudian dari ketiga metode tersebut akan dilakukan perbandingan untuk menentapkan salah satu metode yang akan dipakai untuk mendapatkan laba yang optimal. Dengan demikian ditemukan metode HPP yang tepat, peneliti akan melakukan sosialisasi berupa pelatihan bagaimana cara tepat menentukan harga pokok produk dan bagaimana cara menghitung laba yang optimal jika akan menaikkan kualitas produk. Untuk itu peneliti tertarik mengambil judul penelitian IMPLEMENTASI PENENTUAN HARGA POKOK PRODUKSI UNTUK MENCAPAI LABA OPTIMAL (Studi Pada UKM Industri Bakpia di Wilayah Minomartani Sleman Yogyakarta).

\section{KAJIAN LITERATUR}

\section{Pengertian Harga Pokok Produksi}

Harga Pokok Produk per unit adalah biaya produksi yang dianggap melekat pada setiap unit produknya atau hasil bagi dari total biaya produksi dengan jumlah unit yang dihasilkan dalam satu periode proses produksi. Penentuan harga pokok produk adalah pembebanan biaya yang masuk ke dalam pembuatan produk yang terdiri dari biaya bahan baku, biaya tenaga kerja langsung dan biaya overhead pabrik (Harnanto, 2012).

Activity Based Costing System (ABC)

Pengertian $A B C$ Sistem yang lain juga dikemukakan oleh Hansen and Mowen (2014) sebagai berikut : " $A B C$ atau biaya berdasarkan aktivitas meningkatkan keakuratan dalam mengalokaiskan biaya dengan pertama-tama menelusuri biaya berbagai aktivitas dan kemudian sampai pada produk / pelanggan yang menggunakan berbagai aktivitas tersebut". Activity Based Costing System adalah suatu sistem akuntansi yang terfokus pada aktivitas - aktivitas yang dilakukan untuk menghasilkan produk/ jasa. Activity Based Costing menyediakan informasi perihal aktivitas-aktivitas dan sumber daya yang dibutuhkan untuk melaksanakan aktivitas aktivitas tersebut. Aktivitas adalah setiap kejadian atau transaksi yang merupakan pemicu biaya (cost driver) yakni, bertindak sebagai faktor penyebab dalam pengeluaran biaya dalam organisasi. Aktivitas-aktivitas ini menjadi titik perhimpunan biaya. Dalam sistem $A B C$, biaya ditelusur ke aktivitas dan kemudian ke produk.

\section{Target Costing}

Supriyono (2002) mendefinisikan target costing adalah sistem untuk mendukung proses pengurangan biaya dalam tahap pengembangan dan perencanaan produk model baru tertentu, perubahan model secara penuh atau perubahan model minor. Mulyadi (2007) menjelaskan bahwa target costing adalah suatu metode penentuan biaya produk atau jasa yang didasarkan pada harga (target price) yang diperkirakan dapat diterima oleh konsumen. Hansen dan Mowen (2014) "target costing is a method of a determining the cost of product or service based on the price (target price) that costumer are willing to pay". Jadi, target costing adalah metode penetapan biaya produk yang paling tepat, dan kemudian mendesain dan memproduksi produk yang memenuhi biaya tersebut. Biaya ini dapat menghasilkan tingkat profitabilitas yang diinginkan, volume yang diharapkan, harga penjualan, kualitas dan fungsionalitas produk.

Witjaksono (2013) menyatakan proses penerapan target costing menganut prinsipprinsip sebagai berikut:

\section{Target biaya = Harga pasar - Laba kotor yang dinginkan}




\section{Pengertian Implementasi}

Menurut Usman 2002 Implementasi adalah bermuara pada aktivitas, aksi, tindakan, atau adanya mekanisme suatu sistem. Implementasi bukan sekedar aktivitas, tetapi suatu kegiatan yang terencana dan untuk mencapai tujuan kegiatan". Implementasi harga pokok adalah tindakan untuk menggunakan metode harga pokok produk untuk mencapai tujuan usaha.

Laba Dan Laporan Laba Rugi Perusahaan

Indikator kinerja dari suatu perusahaan adalah laba, karena tujuan utama dari kegiatan operasional yang dijalankan oleh perusahaan adalah memaksimalkan laba. Laba secara operasional merupakan perbedaan antara pendapatan yang direalisasi yang timbul dari transaksi selama satu periode dengan biaya yang berkaitan dengan pendapatan tersebut. Besar kecilnya laba sebagai pengukur kenaikan sangat bergantung pada ketepatan pengukuran pendapatan dan biaya. Menurut Harahap (2012) : laba merupakan angka yang penting dalam laporan keuangan karena berbagai alasan antara lain: laba merupakan dasar dalam perhitungan pajak, pedoman dalam menentukan kebijakan investasi dan pengambilan keputusan, dasar dalam laba. peramalan laba maupun kejadian ekonomi perusahaan lainnya di masa yang akan datang, dasar dalam perhitungan dan penilaian efisiensi dalam menjalankan perusahaan, serta sebagai dasar dalam penilaian prestasi atau kinerja perusahaan.

Laporan keuangan perusahaan salah satunya adalah laporan keuangan. Isi laporan keuangan ini meliputi penjualan dikurangi dengan biaya-biaya. Menurut IAI (2014) Laporan laba rugi merupakan suatu laporan yang sistematis mengenai penghasilan, biaya, rugi laba yang diperoleh oleh suatu perusahaan selama periode tertentu. Tujuan pokok laporan laba rugi adalah melaporkan kemampuan riil perusahaan dalam menghasilkan keuntungan. Laporan laba rugi perusahan disajikan sedemikian rupa yang menonjolkan berbagai unsur kinerja keuangan yang diperlukan bagi penyajian secara wajar.

\section{Kerangka Pemikiran}

Penelitian ini akan meneliti tentang Harga pokok produk yang telah dipakai oleh UKM industri bakpia di Minomartani Sleman kemudian peneliti akan menggunakan perhitungan harga pokok produk bakpia ini berdasarkan metode akuntansi biaya untuk mengoptimalkan 


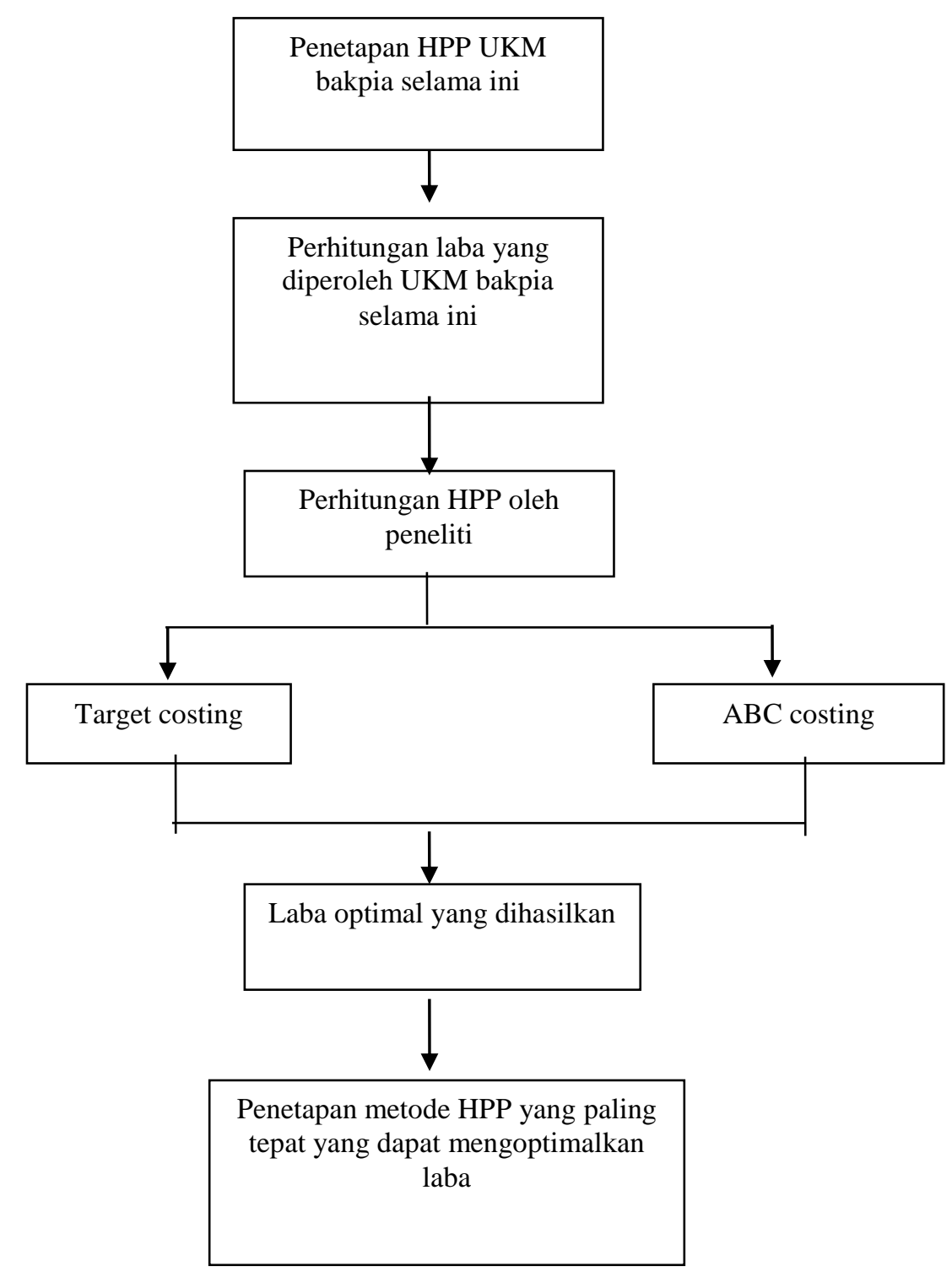

Gambar 1. Kerangka Pemikiran

\section{METODOLOGI PENELITIAN}

Jenis penelitian ini adalah kualitatif dengan pendekatan studi deskriptif yang dipakai dalam penelitian ini, sebagaimana yang diungkapkan oleh Sugiyono, (2012) adalah metode kualitatif untuk mendapatkan data yang mendalam, suatu data yang mengandung makna. Metode kualitatif secara signifikan dapat mempengaruhi substansai penelitian artinya bahwa metode kualitatif menyajikan secara langsung hakikat hubungan antar peneliti dan informan, objek dan subjek penelitian. Selain itu jenis penelitian ini adalah komparatif kuantitatif yaitu jenis penelitian yang bersifat membandingkan variabel yang satu dengan variabel yang lain atau variabel satu dengan standar V. Wiratna (2015)

Penelitian akan dilakukan pada UKM industri Bakpia di Minomartani Sleman Yogyakarta bagian produksi.

Populasi dalam penelitian ini adalah UKM industri bakpia yang ada di wilayah Minomartani Sleman Yogyakarta berjumlah 50 UKM bakpia. Sampel penelitian ini adalah menggunakan insidental sampling, data yang 
digunakan adalah data produksi 1 bulan terakhir.

Sumber Data primer yaitu data penelitian yang diperoleh secara langsung dari sumber asli (tidak melalui media perantara). Dalam penelitian ini data primer diperoleh langsung dari sumbernya dengan melakukan pengamatan langsung serta mengadakan wawancara kepada pemilik UKM industri bakpia di Minomartani Sleman Yogyakarta.

Sumber Data sekunder adalah data yang diperoleh secara tidak langsung dari sumbernya, namun telah terlebih dulu didokumnetasikan oleh pihak lain melalui Studi pustaka dengan meninjau beberapa metode penentuan HPP yang ada padi studi pustaka akuntansi biaya. Selain itu Data-data berasal dari dokumentasi industri bakpia mengenai perhitungan biaya produk yang selama ini dilakukan. Data yang digunakan dalam penelitian ini diambil dari beberapa usaha bakpia di Minomartani Sleman Yogyakarta.

Sesuai dengan tujuan maka langkahlangkah analisis data dalam penelitian ini meliputi (1) Penelaahan data biaya produksi UKM bakpia yang ada di wilayah Minomartani Sleman Yogyakarta (2) Penelaahan penentuan harga pokok produksi yang dipakai UKM bakpia selama ini (3) Berdasarkan hasil data yang sudah diperoleh maka dilakukan perhitungan harga pokok produksi dengan menggunakan metode target costing, ABC Costing. (4) Membandingkan

\section{HASIL DAN PEMBAHASAN}

Sentra UKM Bakpia di wilayah Minomartani Sleman Yogyakarta, walaupun telah berdiri bertahun-tahun, namun banyak dari mereka masih mengalami kesulitan dalam menentukan harga. Dari hasil survei yang dilakukan oleh peneliti bahwa Industri Bakpia di Minomartani Sleman tersebut banyak yang mempunyai permasalahan tidak membuat pembukuan dan kesulitan dalam menentukan harga pokok produknya, sehingga dalam penentuan harga jual mereka masih ketiga metode perhitungan HPP UKM industri bakpia di wilayah Minomartani Sleman. (1) Menelaah laba usaha 1 bulan. (2) Menentukan Metode HPP yang paling tepat untuk mengoptimalkan laba (3) Menguji apakah ada perbedaan laba antara UKM yang selama ini sudah menggunakan perhitungan HPP dengan yang belum menggunakan HPP, dengan menggunakan analisis uji beda independent sampel t-test. Langkah-langkah pengujian hipotesis untuk beda dua rata-rata populasi sama dengan langkah pengujian hipotesis satu rata-rata V. Wiratna Sujarweni (2015)

Rumus untuk menghitung uji statistik Z adalah sebagai berikut:

$$
Z=\frac{\left(\bar{x}_{1}-\bar{x}_{2}\right)-D_{0}}{\sigma_{\left(\bar{x}_{1}-\bar{x}_{2}\right)}}=\frac{\left(\bar{x}_{1}-\bar{x}_{2}\right)-D_{0}}{\sqrt{\frac{\sigma_{1}^{2}}{n_{1}}+\frac{\sigma_{2}^{2}}{n_{2}}}}
$$

Keterangan:

$Z=$ nilai $Z$ 圆ang dihitung

$\bar{x}_{1}=$ Rata - rata $x_{1}$

$\bar{x}_{2}=$ Rata - rata $x_{2}$

$\sigma_{1}=$ Deviasi standar populasi 1

$\sigma_{2}=$ Deviasi standar populasi 2

$n_{1}=$ Jumlah anggota sampel 1

$n_{2}=$ Jumlah ang gota sampel 2

$\mu_{1}-\mu_{2}$ didapat dari pernyataan $\mathrm{H}_{0}: \mu_{1}=\mu_{2}$, sehingga $\mu_{1}-\mu_{2}=D_{0}=0$

menggunakan harga pasaran. Kendala ini membuat mereka tidak mengetahui laba atau rugi yang diperoleh dari usaha selama ini. Untuk menaikkan hargapun mereka tidak berani, karena takut kehilangan pelanggan. Untuk menaikkan kualitas juga mereka masih kesulitan untuk membuat penekananan harga supaya harga tidak naik terlalu tinggi. Dibawah ini hasil surve peneliti yang dilakukan di UKM industri Bakpia di Minomartani tahun 2016. 
Tabel 1. Perhitungan Harga Pokok produk UKM industri bakpia di Minomartani Sleman tahun 2016

\begin{tabular}{|c|c|c|c|}
\hline UKM & $\begin{array}{c}\text { Laporan Laba } \\
\text { rugi }\end{array}$ & $\begin{array}{c}\text { Harga Pokok } \\
\text { Produksi } \\
\end{array}$ & Penentuan harga jual \\
\hline UKM Bakpia 1 & Tidak & tidak menghitung & Sesuai pasaran \\
\hline UKM Bakpia 2 & Tidak & tidak menghitung & Sesuai pasaran \\
\hline UKM Bakpia 3 & Tidak & tidak menghitung & Sesuai pasaran \\
\hline UKM Bakpia 4 & Tidak & tidak menghitung & Sesuai pasaran \\
\hline UKM Bakpia 5 & Tidak & tidak menghitung & Sesuai pasaran \\
\hline UKM Bakpia 6 & Tidak & tidak menghitung & Sesuai pasaran \\
\hline UKM Bakpia 7 & Tidak & $\begin{array}{l}\text { tidak menghitung } \\
\text { berdasar pembelian } \\
\text { harga beli bahan, } \\
\text { tenaga kerja, dan biaya }\end{array}$ & $\begin{array}{c}\text { Sesuai pasaran } \\
\text { Menentukan harga } \\
\text { sendiri }\end{array}$ \\
\hline UKM Bakpia 8 & Tidak & $\begin{array}{c}\text { lainnya } \\
\text { berdasar pembelian } \\
\text { harga beli bahan, } \\
\text { tenaga kerja, dan biaya }\end{array}$ & $\begin{array}{l}\text { Menentukan harga } \\
\text { sendiri }\end{array}$ \\
\hline UKM Bakpia 9 & Tidak & $\begin{array}{c}\text { lainnya } \\
\text { berdasar pembelian } \\
\text { harga beli bahan, } \\
\text { tenaga kerja, dan biaya }\end{array}$ & $\begin{array}{l}\text { Menentukan harga } \\
\text { sendiri }\end{array}$ \\
\hline UKM Bakpia 10 & Tidak & $\begin{array}{c}\text { lainnya } \\
\text { berdasar pembelian } \\
\text { harga beli bahan, } \\
\text { tenaga kerja, dan biaya }\end{array}$ & $\begin{array}{l}\text { Menentukan harga } \\
\text { sendiri }\end{array}$ \\
\hline UKM Bakpia 11 & Tidak & $\begin{array}{c}\text { lainnya } \\
\text { berdasar pembelian } \\
\text { harga beli bahan, } \\
\text { tenaga kerja, dan biaya }\end{array}$ & $\begin{array}{l}\text { Menentukan harga } \\
\text { sendiri }\end{array}$ \\
\hline UKM Bakpia 12 & Tidak & $\begin{array}{c}\text { lainnya } \\
\text { berdasar pembelian } \\
\text { harga beli bahan, } \\
\text { tenaga kerja, dan biaya }\end{array}$ & $\begin{array}{l}\text { Menentukan harga } \\
\text { sendiri }\end{array}$ \\
\hline UKM Bakpia 13 & Tidak & $\begin{array}{c}\text { lainnya } \\
\text { berdasar pembelian } \\
\text { harga beli bahan, } \\
\text { tenaga kerja, dan biaya }\end{array}$ & $\begin{array}{l}\text { Menentukan harga } \\
\text { sendiri }\end{array}$ \\
\hline UKM Bakpia 14 & Tidak & $\begin{array}{c}\text { lainnya } \\
\text { berdasar pembelian } \\
\text { harga beli bahan, } \\
\text { tenaga kerja, dan biaya }\end{array}$ & $\begin{array}{l}\text { Menentukan harga } \\
\text { sendiri }\end{array}$ \\
\hline UKM Bakpia 15 & Tidak & $\begin{array}{c}\text { lainnya } \\
\text { berdasar pembelian } \\
\text { harga beli bahan, } \\
\text { tenaga kerja, dan biaya }\end{array}$ & $\begin{array}{l}\text { Menentukan harga } \\
\text { sendiri }\end{array}$ \\
\hline UKM Bakpia 16 & Tidak & lainnya & \\
\hline
\end{tabular}


UKM Bakpia 17

UKM Bakpia 18

UKM Bakpia 19

UKM Bakpia 20

UKM Bakpia 21

UKM Bakpia 22

UKM Bakpia 23

UKM Bakpia 24

UKM Bakpia 25

UKM Bakpia 26

UKM Bakpia 27

UKM Bakpia 28

UKM Bakpia 29

UKM Bakpia 30
Tidak

Tidak

Tidak

Tidak

Tidak

Tidak

Tidak

Sumber: Pengolahan Data Responden

Dari 30 UKM Bakpia yang ada di sentra Bakpia Minomartani Sleman, hanya 13 UKM yang menetapkan harga jualnya dengan menggunakan harga pokok produk, sedangkan 17 UKM lainnya menetapkan harga jual berdasarkan harga pasaran, walaupun perhitungan mereka masih menggunakan metode yang hanya memperhitungkan biaya bahan baku, biaya tenaga kerja, dan biaya lain-lain. Dari ke 13 UKM yang sudah menghitung harga pokok tersebut ada 1 UKM yang melakukan perhitungan HPP dengan rinci. berdasar pembelian

harga beli bahan, tenaga kerja, dan biaya

$$
\text { lainnya }
$$

berdasar pembelian

harga beli bahan, tenaga kerja, dan biaya

$$
\text { lainnya }
$$

berdasar pembelian

harga beli bahan, tenaga kerja, dan biaya

$$
\begin{gathered}
\text { lainnya } \\
\text { tidak menghitung } \\
\text { tidak menghitung } \\
\text { tidak menghitung } \\
\text { tidak menghitung } \\
\text { berdasar pembelian } \\
\text { harga beli bahan, } \\
\text { tenaga kerja, dan biaya } \\
\text { lainnya } \\
\text { tidak menghitung } \\
\text { tidak menghitung } \\
\text { tidak menghitung } \\
\text { tidak menghitung } \\
\text { tidak menghitung } \\
\text { tidak menghitung }
\end{gathered}
$$

Menentukan harga sendiri

Menentukan harga sendiri

Menentukan harga sendiri

Sesuai pasaran

Sesuai pasaran

Sesuai pasaran

Sesuai pasaran

Menentukan harga sendiri

Sesuai pasaran

Sesuai pasaran

Sesuai pasaran

Sesuai pasaran

Sesuai pasaran

Sesuai pasaran

\section{Perhitungan Harga Pokok Produksi Dan Laba Menurut UKM}

Di bawah ini adalah UKM yang bakpia yang melakukan penghitungan berdasar pembelian harga beli bahan, tenaga kerja, biaya overhead pabrik menurut UKM itu sendiri. Metode penentuan harga pokok produk yang mempertimbangkan semua unsur biaya produksi ke dalam harga pokok produk, yang terdiri dari biaya bahan baku, biaya tenaga kerja langsung, biaya overhead pabrik dihitung oleh UKM dengan ilustrasi sebagai berikut:

Tabel 2. Penghitungan Harga Pokok Produksi menggunakan metode Bakpia Minomartani Bulan September 2016

\begin{tabular}{ccr}
\hline No & Keterangan & Jumlah Biaya \\
\hline 1 & Biaya bahan & Rp 39.700.000
\end{tabular}


Biaya tenaga kerja langsung

Biaya overhead pabrik

Biaya non produksi

Total biaya 1 bulan

Jumlah produksi 1 bulan

Harga pokok produksi
Rp 3.000.000

Rp 6.500.000

Rp 700.000

Rp 49.900.000

60000

Rp 831,67

Sumber: Pengolahan Data Responden

Dari tabel 4.2 merupakan perhitungan harga pokok produksi bakpia menggunakan metode yang selama dipakai oleh UKM tersebut, dalam 1 bulan pada bulan
September 2016 harga pokok produksi per biji bakpia adalah Rp831,67-

Tabel 3. Perhitungan Laba dengan Perhitungan UKM Menggunakan Metode Bakpia Minomartani September 2016

\begin{tabular}{cr}
\hline Kerterangan & Jumlah \\
\hline Harga Jual & Rp 1.000 \\
Jumlah produksi bakpia per bulan & 60.000 \\
Total harga jual & Rp 60.000.000 \\
Biaya produksi per bulan & Rp 49.200.000 \\
Biaya non produksi & Rp 700.000 \\
Total biaya produksi & $\mathbf{R p ~ 4 9 . 9 0 0 . 0 0 0}$ \\
Laba per bulan & $\mathbf{R p ~ 1 0 . 1 0 0 . 0 0 0}$ \\
\hline
\end{tabular}

Sumber: Pengolahan Data Responden

Dengan harga total pokok setiap hari UKM memproduksi bakpia dapat menghasilkan 60.000 biji bakpia. Sehingga per biji bakpia seharga Rp 831,67,-, apabila dilakukan perhitungan laba untuk periode september 2016 menurut perhitungan UKM selama ini mendapatkan laba sebesar Rp 10.100.000,-
Perhitungan Harga Pokok Produksi Dan Laba Menurut Metode Akuntansi Biaya (Metode Target Costing)

Dibawah ini akan disajikan besarnya harga pokok produksi UKM bakpia dengan menggunakan metode target costing adalah sebagai berikut:

Tabel 4. Penghitungan Harga Pokok Produksi Bakpia Minomartani menggunakan metode Target Costing Bulan September 2016

\begin{tabular}{ccr}
\hline No & Keterangan & Jumlah Biaya \\
\hline 1 & Biaya bahan & Rp35.850.000 \\
2 & Biaya tenaga kerja langsung & Rp3.000.000 \\
3 & Biaya overhead pabrik & Rp4.200.139 \\
4 & Biaya non produksi & Rp700.000 \\
5 & Total biaya 1 bulan & Rp43.750.139 \\
6 & Jumlah produksi 1 bulan & 60000 \\
& Harga pokok produksi & Rp729,17 \\
\hline
\end{tabular}

Sumber: Pengolahan Data Responden 
Dari tabel 4.3 merupakan perhitungan harga pokok produksi bakpia menggunakan metode target costing dalam 1 bulan pada bulan September 2016 harga pokok produksi per biji bakpia adalah Rp729,17,-
Dibawah ini akan disajikan besarnya laba yang dihasilkan oleh UKM bakpia dengan menggunakan metode target costing adalah sebagai berikut:

Tabel 5. Perhitungan Laba UKM Bakpia dengan Perhitungan Target Costing Bulan September 2016

\begin{tabular}{cr}
\hline Kerterangan & Jumlah \\
\hline Harga Jual & Rp 1.000 \\
Jumlah produksi bakpia per bulan & 60.000 \\
Total harga jual & Rp 60.000.000 \\
Biaya produksi per bulan & Rp43.050.139 \\
Biaya non produksi & Rp 700.000 \\
Total biaya produksi & $\mathbf{R p ~ 4 3 . 7 5 0 . 1 3 9}$ \\
Laba per bulan & Rp 16.249.861
\end{tabular}

Sumber: Pengolahan Data Responden

Dengan harga total pokok setiap hari UKM memproduksi bakpia dapat menghasilkan 60.000 biji bakpia. Sehingga per biji bakpia seharga Rp 717,50,-, apabila dilakukan perhitungan laba untuk periode september 2016 menurut perhitungan UKM selama ini mendapatkan laba sebesar Rp 16.249.861,-

Perhitungan Harga Pokok Produksi Dan Laba Menurut Metode Akuntansi Biaya (Metode Activity Based Costing)

Metode yang lain dalam akuntansi biaya adalah menggunakan metode ABC, Masalah utama yang sering dijumpai oleh tiap-tiap perusahaan dalam melakukan perhitungan harga pokok produksi adalah mengenai pengalokasian biaya overhead produksi. Biaya overhead harus dialokasikan secara benar dan akurat sehingga menghasilkan perhitungan harga pokok produksi yang tepat. Pada akhirnya dengan perhitungan harga pokok produksi yang tepat tersebut, maka pihak manajemen akan mengambil keputusan yang tepat bagi kepentingan perusahaan.

Perhitungan harga pokok produksi berdasarkan system activity based costing akan disajikan pada tabel 4.5

Tabel 6. Harga Pokok Produksi Berdasarkan Sistem Activity Based Costing

\begin{tabular}{cc}
\hline Keterangan & Perhitngan ABC \\
\hline Bahan baku langsung & Rp35.850.000 \\
Tenaga kerja langsung & Rp3.000.000,00 \\
Biaya Overhead & Rp4.500.466,20 \\
Total Biaya Produksi & Rp43.350.466,20 \\
Volume Produksi (unit) & 60.000 \\
HPP per unit & Rp722,51 \\
\hline
\end{tabular}

Sumber: Pengolahan Data Responden

Pengalokasian biaya overhead sistem activity based costing ini menelusuri setiap aktivitas overhead yang dikonsumsi oleh tiap produk. Dengan adanya penelusuran aktivitas ini, maka dapat diketahui besarnya biaya yang benar-benar diserap oleh masing-masing produk tersebut selama proses produksinya. Dapat disimpulkan bahwa besarnya alokasi 
biaya overhead yang diterima tiap produk tidak memandang jumlah volume produksi produk yang bersangkutan, tetapi didasarkan atas aktivitas-aktivitas yang terjadi saat produk tersebut diproduksi. Sistem ini dilandaskan atas dasar bahwa suatu produk memerlukan aktivitas dan aktivitas mengkonsumsi sumber daya, sumber daya yang dikonsumsi ini menimbulkan biaya. Dari hasil perhitungan harga pokok produksi berdasarkan sistem activity based costing maka diperoleh harga pokokproduksi adalah sebesar Rp722,51 per biji bakpia,

Tabel 7. Perhitungan Laba dengan Perhitungan UKM Bakpia Menurut Metode ABC

\begin{tabular}{cc}
\hline Kerterangan & Jumlah \\
\hline Harga Jual & Rp1.000 \\
Jumlah produksi bakpia per bulan & 60.000 \\
Total harga jual & $\mathbf{R p 6 0 . 0 0 0 . 0 0 0}$ \\
Biaya produksi per bulan & Rp43.350.466,20 \\
Laba per bulan & Rp16.949.534
\end{tabular}

Sumber: Pengolahan Data Responden

Dengan harga total pokok setiap hari UKM memproduksi bakpia dapat menghasilkan 60.000 biji bakpia. Sehingga per biji bakpia seharga Rp 722,51,-, apabila dilakukan perhitungan laba untuk periode september 2016 menurut perhitungan UKM selama ini mendapatkan laba sebesar Rp 16.949.534,-

\section{Analisa Perbandingan Harga Pokok Produksi Berdasarkan Perhitungan UKM}

\begin{abstract}
dengan Metode Target Costing, Activity Based Costing (ABC)

Terdapat perbedaan harga pokok produksi yang dilaporkan oleh UKM dengan sistem UKM tersebut dengan harga pokok produksi yang menggunakan metode akuntansi target costing, system activity based costing. Hal ini dapat terlihat pada tabel 4.20 dan tabel 4.7
\end{abstract}

Tabel 8. Perbandingan Harga Pokok Produksi Menurut UKM, Target Costing, dan Activity Based Costing

\begin{tabular}{|c|c|c|c|c|}
\hline No & Keterangan & UKM & Target Costing & $\mathbf{A B C}$ \\
\hline 1 & Biaya bahan & Rp39.700.000 & Rp35.850.000 & Rp35.850.000 \\
\hline 2 & $\begin{array}{l}\text { Biaya tenaga kerja } \\
\text { langsung }\end{array}$ & Rp3.000.000 & Rp3.000.000 & Rp3.000.000,00 \\
\hline 3 & Biaya overhead pabrik & Rp6.500.000 & Rp4.200.139 & $\mathrm{Rp} 4.500 .466,20$ \\
\hline 4 & Biaya non produksi & Rp700.000 & Rp700.000 & \\
\hline 5 & Total biaya 1 bulan & Rp49.900.000 & Rp43.750.139 & 43.350 .466 \\
\hline \multirow[t]{2}{*}{6} & Jumlah produksi 1 bulan & 60000 & 60000 & Rp60.000,00 \\
\hline & Harga pokok produksi & Rp831,67 & Rp729,17 & 722,51 \\
\hline
\end{tabular}

Sumber: Pengolahan Data Responden

Harga pokok produksi bakpia menurut cara perhitungan UKM sebesar Rp831,67 perbiji, kemudian menurut harga pokok produksi target costing sebesar Rp 729,17 dan menurut metode ABC Rp722,51. 
Tabel 9. Perbandingan Laba Menurut UKM, Target Costing, dan Activity Based Costing

\begin{tabular}{crrr}
\hline Kerterangan & \multicolumn{1}{c}{ UKM } & Target Costing & \multicolumn{2}{c}{ ABC } \\
\hline Harga Jual & Rp1.000 & Rp1.000 & Rp1.000 \\
Jumlah produksi bakpia per & 60.000 & 60.000 & 60.000 \\
bulan & & & Rp60.000.000 \\
Total harga jual & Rp60.000.000 & Rp60.000.000 & Rp43.350.466,20 \\
Biaya produksi per bulan & Rp49.200.000 & Rp43.050.139 & \\
Biaya non produksi & Rp700.000 & Rp700.000 & \\
Total biaya produksi & Rp49.900.000 & Rp43.750.139 & Rp43.350.466,20 \\
Laba per bulan & Rp10.100.000 & Rp16.249.861 & Rp16.649.533,80 \\
\hline
\end{tabular}

Sumber: Pengolahan Data Responden

Laba yang dihasilkan menurut cara perhitungan UMKM sebesar Rp10.100.000, kemudian menurut metode target costing laba sebesar Rp 16.249.861 dan laba menurut metode ABC Rp 16.649.533,80.

\section{Hasil Uji Beda Perolehan Laba Antara UKM Bakpia Yang Sudah Menerapkan}

\section{Menerapkan Metode Penentuan HPP Dan Yang Belum}

Dibawah ini akan disajikan hasil uji perbedaan perolehan laba antara UKM bakpia yang sudah menerapkan menerapkan metode penentuan HPP dan yang belum adalah sebagai berikut:

Tabel 10. Hasil Uji Beda Perolehan Laba Antara UKM Bakpia Yang Sudah Menerapkan Metode penentuan HPP dan yang belum

\begin{tabular}{cr}
\hline Keterangan & Nilai \\
\hline Sig t & 0,006 \\
Rata-rata laba tidak menghitung HPP & Rp2.326.471 \\
Rata-rata laba menggunakan metode HPP & Rp 4.796.154 \\
\hline
\end{tabular}

Sumber: Pengolahan Data Responden

Nilai sig t hitung 0,006 oleh karena nilai sig $\mathrm{t}$ hitung $<0,05$ yang berarti Ho ditolak artinya ada perbedaan perolehan laba antara UKM bakpia yang sudah menerapkan menerapkan metode penentuan HPP dan yang belum. Perbedaan perolehan laba untuk UKM bakpia yang belum menghitung HPP yaitu rata-rata sebesar Rp2.326.471 sedangkan yang sudah melakukan perhitungan HPP memperoleh laba perbulan rata-rata adalah sebesar $\mathrm{Rp}$ 4.796.154

\section{SIMPULAN}

Dari 30 UKM Bakpia yang ada di sentra Bakpia Minomartani Sleman, hanya 13 UKM yang menetapkan harga jualnya dengan menggunakan harga pokok produk, sedangkan
17 UKM lainnya menetapkan harga jual berdasarkan harga pasaran.

Harga pokok produksi bakpia menurut cara perhitungan UKM sebesar Rp831,67 perbiji, kemudian menurut harga pokok produksi target costing sebesar Rp 729,17 dan menurut metode ABC Rp722,51.

Harga pokok produksi bakpia menurut cara perhitungan UKM sebesar Rp831,67 perbiji, kemudian menurut harga pokok produksi target costing sebesar Rp 729,17 dan menurut metode ABC Rp722,51. Jadi perhitungan yang digunakan untuk menghitung harga pokok produksi yang direkomendasikan dipakai adalah metode $\mathrm{ABC}$ karena menghasilkan perhitungan harga pokok produksi yang paling dapat ditekan sehingga dapat mengoptimal laba UKM. Laba yang dihasilkan menurut cara perhitungan UKM sebesar Rp10.100.000, kemudian 
menurut metode target costing laba sebesar Rp 16.249.861 dan laba menurut metode ABC Rp 16.649.533,80,-. Laba yang paling optimal dihasilkan dari perhitungan bakpia dengan metode ABC.

Ada perbedaan perolehan laba antara UKM bakpia yang sudah menerapkan menerapkan metode penentuan HPP dan yang belum. Perbedaan perolehan laba untuk UKM bakpia yang belum menghitung HPP yaitu rata-rata sebesar Rp2.326.471 sedangkan yang sudah melakukan perhitungan HPP memperoleh laba perbulan rata-rata adalah sebesar Rp 4.796.154.

Sarana dalam penelitian ini yaitu UKM Bakpia Minomartani Sleman sebaiknya menggunakan perhitungan harga pokok produksi dengan menggunakan metode $\mathrm{ABC}$ karena lebih terinci dan tepat dalam menghitung harga pokok produksi serta metode $\mathrm{ABC}$ menghitung biaya secara keseluruhan. Selain itu Perlu diadakan pelatihan dan sosialisasi cara menghitung harga pokok produksi, menghitung laba dan membuat laporan keuangan UKM bakpia.

\section{DAFTAR PUSTAKA}

Anton. (2012). Analisis Penentuan Harga Pokok Produksi Menggunakan Metode Activity Based Costing (Studi Kasus Pada PT. Bintang Semarang). Majalah Ilmiah INFORMATIKA, 3(3).

Carter, William K dan Milton F. (2014). Akuntansi Biaya.Penerjemah (Ketiga bel). Jakarta: Salemba Empat.

Harahap, Sofyan Safri. 2012. Teori Akuntansi. Penerbit : PT. Raja Grafindo Persada, Jakarta.

Hansen, Don R., and Maryanne M. Mowen 2014. Management Accounting, Cincinnati. Ohio: South Western Pulising Co.

Mulyadi., 2012. Akuntansi Biaya. Penerbit : Aditya Media. Yogyakarta.

Mulyadi. 2007. Akuntansi Manajemen: Konsep, Manfaat, dan Rekayasa. Penerbit : STIE YKPN
Pradana Setiadi, David P.E. Saerang, Treesje Runtu 2014. Perhitungan HPP dalam penentuan harga jual CV Minahasa Mantab perkasa. Jurnal Berkala Ilmiah Efisiensi.: Volume 14 no. 2

Singarimbun, M. dan Effendi, S., 2006, Metode Penelitian Survai, Cetakan Kedelapanbelas, Penerbit : Pustaka LP3ES, Jakarta.

Silvia Porawouw. 2013. Analisis perbandingan metode penentuan harga pokok produksi pada PT Bangun Wenang Baverage S Co. Jurnal EMBA. Vol.1 No.4, Hal. 1946-1952

Supriyono, R.A. 2002. Akuntansi Biaya dan Akuntansi Manajemen untuk Teknologi Maju dan Globalisasi. Penerbit : BPPE Yogyakarta.

Usman, Nurdin. 2002. Konteks Implementasi Berbasis Kurikulum. Penerbit : PT. Raja Grafindo Persada. Jakarta.

V. Wiratna Sujarweni. 2015 Statistik Bisnis dan Ekonomi. Penerbit : Pustaka Baru 2015

Witjaksono. 2013. Akuntansi Biaya. Edisi Revisi. Penerbit : Graha Ilmu Yogyakarta

Zulfi, Harisman.2012. Analsis perbandingan harga pokok produksi metode konvensional dengan metode activity based costing (ABC) dalam perhitungan harga jual Studi Kasus Pada CV Bachtiar Offset Tasikmalaya. Jurnal Universitas Siliwangi. 


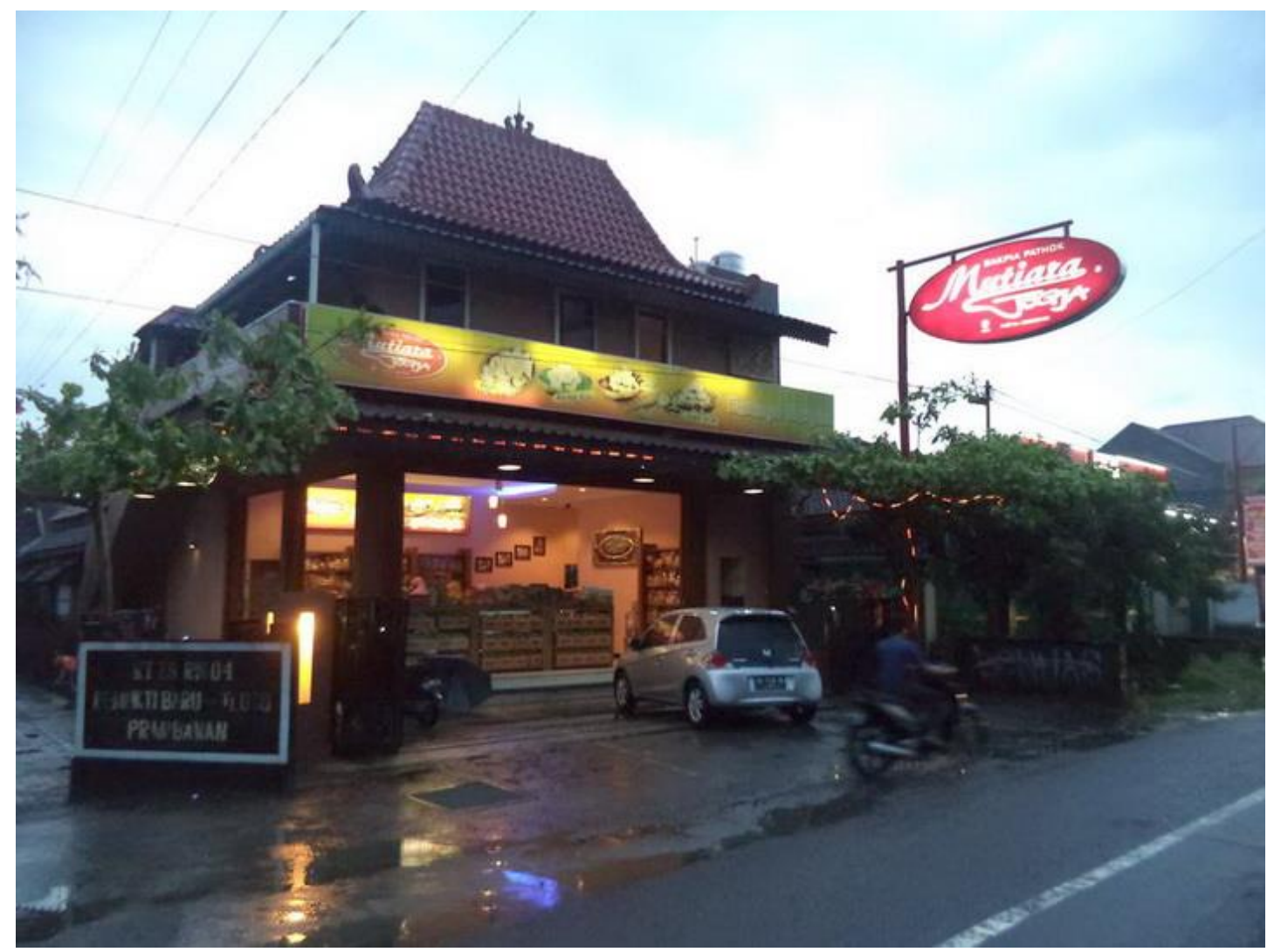

http://desainarsitek.net/wp-content/uploads/2016/03/Eksisting-Bakpia-Mutiara-Jogja-04.jpg

Toko Bakpia Mutiara yang dimiliki oleh Bapak Yudi untuk mendesain ulang tokonya yang berada di Jalan Manisrenggo, Prambanan, Jogja. Bakpia Mutiara ini adalah salah satu usaha bakpia dengan banyak gerai yang tersebar di Jogja. Ukuran ruang gerai toko Bakpia Mutiara adalah 6,3 x 5,4 m. Sisi utara ruang digunakan untuk meja kasir, sedang sisi-sisi lainnya digunakan sebagai area untuk display produknya. Klien kami tersebut mengingingkan sebuah desain baru yang fresh dan mampu membuat ruang yang sempit menjadi terkesan luas / lebar. 